\title{
PENCABUTAN HAK POLITIK TERPIDANA KORUPSI \\ DALAM PERSPEKTIF SOCIAL CONTRACT THEORY
}

\author{
Indra Karianga, \\ Haikal Arsalan, \\ Lidya Josephine Yubagyo, \\ Cavita Ezra
}

Fakultas Hukum Universitas Airlangga

J1.Airlangga No.4-6 Surabaya, 60115

Email: in.karianga-2018@fh.unair.ac.id

\begin{abstract}
This research aim is to provide a theoretical basis to permanently remove the political rights of a former prisoners of corruption as an alternative to achieve the purpose of criminal law. This normative research uses conceptual, statute and philosophical approach method. This research result indicate that based on the social contract theory, corruption is a criminal act which has injured the volonte generale and in this regard, a new concept is offered. The new concept is permanent revocation of political rights for a former coruption convicts that in line with peines infarmantes principle but does not apply automatically and must go through a court decision and be apllied for life (restitutio in integrum).
\end{abstract}

Keywords: Revocation of Political Rights, Corruption Prisoner, Social ContractTheory.

\begin{abstract}
Abstrak
Tujuan penelitian ini adalah untuk memberikan landasan teoritis agar pencabutan hak politik terhadap terpidana korupsi diberlakukan secara permanen sebagai alternatif untuk mencapai tujuan hukum pidana. Penelitian hukum normatif ini menggunakan pendekatan konseptual, perundang-undangan dan pendekatan filosofis. Hasil menunjukan bahwa berdasarkan social contract theory, tindak pidana korupsi merupakan tindak pidana yang telah mencederai kehendak umum (volonte generale). Terhadap hal tersebut ditawarkan konsep baru yakni pencabutan hak politik secara permanen bagi terpidana korupsi sesuai dengan prinsip peines infarmantes namun tidak berlaku secara otomatis melainkan harus melaui putusan pengadilan dan berlaku seumur hidup (restitutio in integrum).
\end{abstract}

Kata Kunci: Pencabutan Hak Politik, Terpidana Korupsi, Teori Kontrak Sosial. 


\section{Latar Belakang}

Hukum pidana kontemporer secara teoritis memiliki 3 tujuan, yakni Teori efek jera, Teori edukasi dan Teori rehabilitasi. Teori efek jera dikemukakan oleh Wayane R.Lafave yang menyebutkan tujuan hukum pidana salah satunya membuat pelaku kejahatan menjadi jera dan tidak lagi mengulangi perbuatannya. Teori edukasi yang menyatakan bahwasanya tujuan dari pemidanaan adalah sebagai edukasi kepada masyarakat mengenai perbuatan mana yang baik dan buruk. Teori rehabilitasi artinya tujuan pemidanaan untuk memperbaiki pelaku kejahatan ke arah yang baik, agar ketika mereka kembali ke dalam masyarakat dapat diterima dan tidak lagi mengulangi perbuatan jahat. ${ }^{1}$ Ketika seseorang dipidana maka harus memenuhi tujuan dari pemidanaan kontemporer yaitu memberikan efek jera serta merehabilitasi dari tindakan buruk agar ketika terpidana bebas maka yang bersangkutan tidak lagi melakukan tinndak pidana. Namun, masih terdapat terpidana yang melakukan tindak pidana setelah bebas. Dalam kenyataannya (das sein) masih terdapat residivis kasus korupsi yang merupakan extraordinary crime atau kejahatan luar biasa. Misalnya pada saat ini, H. ABDUL LATIF yang pada tahun 2005 yang bersangkutan seorang pengusaha. Kasusnya telah diputus di pengadilan, yang bersangkutan divonis satu setengah tahun penjara. Latif tersangkut kasus korupsi pembangunan Unit Sekolah Baru (USB) Sekolah Menengah Atas Negeri 1 Labuan Amas Utara dengan anggaran Rp711,880 juta. Latif mencalonkan diri menjadi Anggota DPRD Kalimantan Selatan periode 2014-2019. Dia menjadi caleg dari daerah pemilihan IV meliputi Kabupaten Tapin, Hulu Sungai Tengah, dan Hulu Sungai Selatan. Yang bersangkutan kemudian terpilih sebagai anggota DPRD Kalimantan Selatan periode 2014-2019.2 Pada tahun 2018 yang bersangkutan kembali melakukan tindak pidana yang diputus oleh pengadilan tinggi Jakarta lewat putusan nomor 28/Pid. Sus-TPK/2018/PT.DKI Tahun 2018. Sebagai terhukum, Lutfi masih melakukan upaya hukum kasasi. Dalam amar putusan nomor 28/ Pid.Sus-TPK/2018/PT.DKI hakim juga turut menjatuhkan pidana tambahan pencabutan hak poltik selama tiga tahun. ${ }^{3}$

Hukum yang dituangkan dalam peraturan perundang-undangan tidak memberikan pencabutan hak politik secara permanen. Hal ini menyebabkan ketika terpidana korupsi bebas, mereka masih dapat mencalonkan diri kembali sebagai anggota legislatif. Walaupun menurut data dari KPK yang dikatakan oleh juru biscara KPK Febri Diansyah bahwa sepanjang tahun 2013-2017, pengadilan tindak pidana korupsi (tipikor) telah mencabut

1 Edy O.S. Hiariej, Prinsip-Prinsip Hukum Pidana Edisi Revisi, (Yogyakarta: Cahaya Atma Pustaka, 2016), hlm. $42-43$

2 Julian,."Bupati.Ini.Ternyata.Residivis.Kasus.Korupsi”http://poskotanews.com/2018/01/06/bupati-initernyata-residivis-kasus-korupsi/, diakses 20 mei 2019.

3 Vide: putusan nomor 28/Pid.Sus-TPK/2018/PT.DKI 
hak politik 26 koruptor yang terbukti terlibat dalam kasus korupsi. 26 orang tersebut ada yang menjabat sebagai ketua umum dan pengurus parpol, anggota DPR dan DPRD, kepala daerah serta jabatan lain yang memiliki risiko publik besar jika menjadi pemimpin politik. ${ }^{4}$ Secara yuridis karena pencabutan hak politik tidak secara permanen maka setelah melebihi batas waktu pencabutan hak politik berakhir yang bersangkutan dapat mencalonkan kembali. Seperti pada Tahun 2019 ini, Negara Indonesia tengah memasuki tahun politik dimana diselenggarakannya pemilihan umum serentak pada tanggal 17 April 2019. Selain memilih Presiden dan Wakil Presiden, Warga Negara Indonesia juga memilih anggota legislatif. Terhitung tanggal 20 Februari 2019, tercatat sebanyak 81 calon anggota legislatif yang merupakan eks koruptor. ${ }^{5}$ Dalam perkembangannya, terdapat pembatasan hak politik dimana warga negara terpidana yang telah mendapatkan putusan pengadilan (inkracht) 5 tahun penjara atau lebih tidak dapat mencalonkan diri sebagai anggota legislatif, kecuali secara terbuka dan umum yang bersangkutan mengemukakan pada publik bahwa sebelumnya pernah dipidana. ${ }^{6}$ Dalam hal ini, tindak pidana yang dimaksud adalah tindak pidana korupsi. Hak politik terpidana korupsi tidak pernah dibatasi secara tegas, dikarenakan terdapat pengecualian yang akhirnya berimplikasi secara yuridis terhadap para terpidana dimana mereka diperbolehkan untuk mencalonkan diri kembali sebagai anggota legislatif. Selain itu seringkali, pencabutan tersebut ditetangkan dengan sisi hak asasi manusia karena Indonesia sendiri menjamin terhadap perlindungan Hak Asasi Manusia. ${ }^{7}$

Dari 81 caleg, 23 caleg eks koruptor maju untuk Dewan Perwakilan Rakyat Daerah (DPRD) provinsi, 49 caleg eks koruptor maju tingkat DPRD kabupeten/kota, dan 9 merupakan calon legislatif Dewan Perwakilan Daerah (DPD). ${ }^{8}$

Plato, seorang filsuf Yunani menyatakan nemo prudens punit, quia pecatum, sed ne peccetur yang berarti seorang yang bijaksana tidak akan menghukum dengan alasan karena telah melakukan dosa, melainkan agar tidak terjadi lagi dosa. ${ }^{9}$ Ungkapan ini merujuk pada tujuan pemidanaan yang fokusnya adalahagar tidak terjadinya kejahatan yang sama. Maka sangat penting untuk menjalankan sistem peradilan pidana agar dapat membuat tercapainya tujuan hukum

4 Dylan Aprialdo Rachman, “KPK: Hak Politik 26 Koruptor Dicabut Sepanjang 2013-2017”,https://nasional. kompas.com/read/2018/09/18/13252541/kpk-hak-politik-26-koruptor-dicabut-sepanjang-2013-2017, diakses 20 mei 2019

5 Moh. Dani Pratama Huzaini, “Update KPU, Jumlah Caleg Mantan Napi Koruptor Bertambah 32 Orang” https:// www.hukumonline.com/berita/baca/lt5c6ca7a634887/iupdate-i-kpu--jumlah-caleg-mantan-napi-koruptorbertambah-32-orang., diakses 24 Februari 2019.

6 Pasal 240 Undang-Undang Nomor 7 Tahun 2017 tentang Pemilihan Umum.

7 Sabungan Sibarani, “Analisis Hukum Mengenai Pencabutan Hak Politik Bagi Koruptor Berdasarkan Sudut Pandang Hak Asasi Manusia, Prosiding Seminar Nasional Pakar ke-2 Sosial dan Humaniora, 2019, buku ke-2, hlm. 4.

8 Fitria Chusna Farisa, "Daftar Lengkap 81 Caleg Eks Koruptor”, https://nasional.kompas.com/ $\mathrm{read} / 2019 / 02 / 19 / 15075331 /$ daftar-lengkap-81-caleg-eks-koruptor?page=all, diakes 6 Mei 2019.

9 Ibid. 
pidana kontemporer khususnya dalam sistem peradilan pidana. Sistem peradilan pidana atau sistem penegakan hukum, secara integral, merupakan sebuah kesatuan yang di dalamnya terdiri dari sub sistem atau komponen subtansi hukum, struktur hukum dan kultur hukum. Struktur hukum adalah lembaga atau aparat penegak hukum. ${ }^{10}$

Secara filosofis, seorang pejabat mendapatkan kepercayaan dari rakyat. Berdasarkan Contract Social Theory (Teori Kontrak Sosial) sebagaimana dikemukakan oleh Thomas Hobes dan Rousseau, para pejabat memegang kepercayaan rakyat untuk dapat memenuhi dan mengutamakan kepentingan rakyat itu sendiri. Isu hukum yang kemudian muncul adalah lantas bagaimanakah jika pejabat tersebut ternyata mengkhianati kepercayaan rakyat dan mementingkan atau memperkaya diri sendiri serta akhirnya rakyat yang menjadi korban? Apakah pejabat tersebut masih dapat diberikan kepercayaan lagi? Lalu bagaimanakah cara memulihkan kepercayaan rakyat terhadap pejabat yang pada dasarnya memegang tanggungjawab penuh atas kepentingan rakyat (social contract theory)?

Berangkat dari isu hukum tersebut, maka penulis tertarik untuk melakukan penelitian tentang Pencabutan Hak Politik Sebagai Pidana Tambahan Terhadap Terpidana Korupsi Ditinjau dari Perspektif Social Contract Theory (Teori Kontrak Sosial). Dikarenakan pencabutan hak politik yang tidak berlaku permanen maka, diperlukan terobosan hukum untuk mencabut hak politik secara permanen serta mencegah para pejabat melakukan bahkan mengulangi tindak pidana korupsi. Selain itu, pembahasan mengenai pidana sangat penting karena sejalan dengan pendapat Helbert Pecker. Yang menyatakan bahwa dalam hukum pidana, pemberian pidana merupakan masalah utama selain kejahatan dan kesalahan itu sendiri. ${ }^{11}$ Berdasarkan hal tersebut kemudian memunculkan rumusan masalah sebagai berikut:

1. Bagaimana konsep pencabutan hak sebagai pidana tambahan dalam hukum pidana di Indoensia?

2. Bagaimana pencabutan hak politik bagi terpidana korupsi dalam perspektif social contract theory?

Penelitian ini merupakan penelitian hukum normatif dengan menggunakan metode pendekatan konseptual (conceptual approach), pendekatan perundang-undangan (statute approach) dan pendekatan filosofis (philosophical approach). Pendekatan konseptual (conceptual approach) digunakan untuk menelaah konsep pencabutan hak politik sebagai pidana tambahan dan menghasilkan konsep baru sebagai alternatif untuk mencapai tujuan dari pemidanaan itu sendiri. Hal ini berkaitan dengan tujuan hukum pidana kontemporer, bahwa pidana pokok dirasa tidak cukup memberikan efek jera dan edukasi bagi para pelaku tindak pidana, khususnya dalam hal ini caleg eks koruptor. Oleh karena itu disamping adanya pidana

10 Syaiful Bakhri, Sistem Peradilan Pidana di Indonesia Dalam Perspektif Pembaruan, Teori, dan Praktik Peradilan, (Yogyakarta: Pustaka Pelajar, 2016), hlm.146.

11 Warih Anjari, "Pencabutan Hak Politik Terpidana Korupsi dalam Perspektif Hak Asasi Manusia, Jurnal Yudisial, Volume 8 Nomoer 1, April 2015, hlm. 24. 
pokok terdapat juga pidana tambahan yang salah satunya mencakup pencabutan hak-hak tertentu termasuk hak politik. Selanjutnya, statute approach digunakan untuk melihat pencabutan hak-hak tertentu sebagai pidana tambahan yang diatur dalam KUHP maupun ketentuan perundang-undangan diluar KUHP. Sedangkan, pendekatan filosofis (philosophical approach) digunakan pada pembahasan pertama untuk mengetahui ratio legis dari adanya konsep pencabutan hak sebagai pidana tambahan dalam hukum pidana di Indonesia dan pembahasan kedua mengenai pencabutan hak politik bagi terpidana korupsi dalam perspektif social contract theory untuk mengetahui dasar secara ontologis dari hak masyarakat sebagai pemilik kedaulatan tertinggi sebagaimana yang telah diatur dalam Pasal 1 ayat (2) Undang-Undang Dasar Negara Republik Indonesia Tahun 1945.

\section{Pembahasan}

\section{A. Konsep Pencabutan Hak Sebagai Pidana Tambahan Dalam Hukum Pidana di Indonesia.}

Pencabutan hak politik tidak terlepas dari adanya pidana pokok, oleh karenanya perlu untuk mengetahui ratio legis adanya pidana pokok dan pidana tambahan. Aturan yang pertama mengatur pencabutan hak tertentu sebagai pidana tambahan adalah dalam KUHP. Proses dalam memahami ratio legis adanya pidana tambahan adalah dengan melihat bagaimana pidana pokok dan pidana tambahan di Belanda. Hal tersebut dikarenakan KUHP sebagai produk peninggalan Belanda yang tidak terlepas dari hukum Romawi yang kemudian diturunkan ke Prancis dan kemudian ke Belanda. Hukum pidana merupakan sarana untuk memerangi kriminalitas, itulah konsep dasar yang kemudian memunculkan pidana pokok (hoofdstraffen) dan pidana tambahan (bijkomendestraffen). Jenis-jenis pidana pokok yaitu pidana penjara (gevangenisstraf), pidana kurungan (hehtenis), pidana kerja sosial serta pidana harta benda (vermogensstraffen) dan denda (geldboete). Pidana tambahan kemudian dibagi menjadi empat bagian yaitu pencabutan hak-hak tertentu (ontzetting van bepaalde rechten), melakukan pekerjaan tertentu di dalam institusi Negara, pidana perampasan barang-barang tertentu (uerbeurdverklaring van bepaalde voorwerpen), serta pengumuman putusan hakim (openbaarmaking van de rechterlijke uitspraak). ${ }^{12}$ Pidana penjara adalah salah satu jenis pidana pokok yakni perampasan kemerdekaan. ${ }^{13}$ Pidana pokok yang dianut oleh Amerika Serikat menunjukkan bahwa pidana merupakan cara untuk mengarahkan terpidana pada penyesalan, pertobatan dan seterusnya. Terpidana kemudian melalui isolasi dalam kesenyapan serta kekosongan dipercaya akan menciptakan pertobatan diri, oleh karena itu

\footnotetext{
12 Jan Remmelink, Hukum Pidana Komentar Atas Pasal-pasal Terpenting Dari Kitab Undang-Undang Hukum Pidana Belanda dan Padanannya Dalam Kitab Undang-Undang Hukum Pidana Indonesia, (Jakarta: Gramedia Pustaka Utama,2003), hlm.463.
}

13 Ibid., hlm.465. 
terpidana tidak diberikan kerja paksa maupun hak kunjungan. Hal ini sebagai the most rigid and unremitted solitude. ${ }^{14}$ Namun, sangat disayangkan proses isolasi tersebut ternyata gagal memunculkan pertobatan dalam diri terpidana. Hasil yang mengecewakan tersebut kemudian akhirnya membuat pemerintah melakukan perombakan dimana yang semula tidak ada kerja paksa sekarang diterapkan kerja paksa serta kunjungan dan seterusnya diperkenankan bagi terpidana. ${ }^{15}$

Keseluruhan sistem pemidanaan memiliki tujuan yakni untuk mengembalikan terpidana kedalam masyarakat dengan keadaan yang lebih baik, tetapi hal yang sangat esensial yakni pada waktu terpidana menjalani hukuman penjara dalam jangka waktu yang ditentukan lewat vonis hakim haruslah dimanfaatkan demi kepentingan reclassering yaitu kepentingan pemasyarakatan atau pembinaan. ${ }^{16}$ Kepentingan reclassering berhubungan dengan tujuan pidana kontemporer yakni teori efek jera Wayne R. Lafave, teori edukasi dan teori rehabiltiasi. ${ }^{17}$ Hubungan tersebut terlihat ketika terpidana itu dibina dalam lembaga pemasyarakatan maka pembinaan itu akan berjalan dengan baik jika terpidana dibuat jera agar tidak mengulangi kejahatan, dipulihkan atau direhabilitasi agar terpidana merasa bersalah dan menjadi masyarakat yang baik setelah yang bersangkutan bebas, dan ketika pembinaan berjalan dengan baik secara langsung atau tidak langsung memberikan edukasi kepada masyarakat.

Kepentingan pembinaan atau permasyarakatan reclassering jika berjalan dengan baik maka akan membuat tercapainya tujuan sistem peradilan pidana (criminal justice system) yang terdiri dari tiga poin penting yaitu: ${ }^{18}$ Sebuah langkah preventif untuk mencegah masyarakat menjadi korban kejahatan.

Menjadi kunci penyelesaian kasus kejahatan sehingga masyarakat merasa puas bahwa keadilan telah ditegakkan dan yang terbukti bersalah dipidana.

Membuat para pelaku yang pernah melakukan kejahatan agar tidak mengulangi lagi tindak pidana atau tidak lagi berbuat kejahatan.

Dari pengertian sistem peradilan pidana diatas dapat dipahami bahwa perbuatan pidana atau kejahatan itu haruslah dihukum. Mengingat tindak pidana korupsi merupakan kejahatan yang mengorbankan Negara, khususnya masyarakat, maka ketika pelaku dihukum, masyarakat akan merasa puas. Dalam melaksanakan pidana pokok terhadap pelaku tindak pidana korupsi, tiga tujuan pemidanaan kontemporer harus tercapai dengan mengikuti sistem peradilan pidana guna menciptakan keadilan bagi korban 
(negara dan masyarakat).Namun, penjatuhan pidana pokok terkadang tidak mencapai tujuan hukum pidana kontemporer sehingga pemberian sanksi pidana tambahan dianggap perlu dilakukan. Poin dari tujuan sistem peradilan pidana tidak hanya mencakup langkah represif semata, tetapi juga mencakup langkah preventif guna mencegah masyarakat menjadi korban kejahatan. Salah satu langkah preventif yang akan dibahas adalah mengenai pencabutan hak-hak tertentu.

Istilah dari pencabutan berbeda dengan pemberhentian atau pemecatan karena kata pencabutan hanya menyatakan tidak adanya hak seseorang. Berbeda dengan pemecatan atau pemberhentian yang merupakan hak dari atasan untuk memecat atau memberhentikan seseorang. ${ }^{19}$ Konsep pencabutan hak itu sendiri jika dilihat dari segi historis sudah sejak lama yaitu dalam hukum Romawi disebut Infamia yang kemudian dimasukan dalam Code Penal dengan nama Pienes Infamantes. Setelah dimasukan dalam kode penal, kemudian di waktu penjajahan Napoleon Bonaparte akhirnya sempat di bawa ke Belanda. ${ }^{20}$ Kata Infamia berarti hilangnya sejumlah hak istimewa sebagai warga romawi atau hilangnya kehormatan. Selanjutnya ada juga deminutio existimationis yang berarti pengurangan kehormatan. Hukuman yang demikian tidak dijatuhkan, melainkan diberlakukan secara otomatis dan berlaku seumur hidup atau yang biasa dikenal dengan sebutan restitutio in intergrum. Hukuman ini wujudnya adalah pencabutan keseluruhan hak privat maupun publik terpidana, termasuk hak politik untuk dipilih sebagai pejabat publik. ${ }^{21}$ Sebagai contoh anggota legislatif yang telah terbukti melakukan tindak pidana korupsi, akan diberlakukan prinsip peines infarmantes yakni pencabutan hak politik dengan alasan bahwa pejabat telah melakukan kejahatan berat yang telah merugikan rakyat. Penerapan prinsip peines infarmantes mengandung nilai keadilan yang selaras dengan tujuan pemidanaan dan tujuan sistem peradilan pidana yaitu sebagai langkah preventif untuk mencegah masyarakat dapat menjadi korban kejahatan tindak pidana korupsi.

Degradasi serupa merupakan tujuan dari prinsip peines infarmantes, sebagaimana telah diatur dalam Code Penal yang berlaku sampai tahun 1886. Prinsip pienes Infarmates di dalamnya jika terjadi kejahatan berat atau kejahatan-kejahatan serius seperti penggelapan uang. Misalnya seorang hakim yang terbukti melakukan kejahatan serius seperti penggelapan uang maka status sebagai warga terhomat dicabut dengan sendirinya tanpa putusan pengadilan dan yang bersangkutan tidak lagi dapat memegang profesi tersebut. Namun, ketentuan ini kemudian dicabut dengan diberlakukannya KUHP Belanda yang baru pada tahun 1886. Pelaku tindak pidana

19 S.R. Sianturi \& Mompang L. Panggabean, Hukum Penitensia di Indonesia, (Jakarta: AlumniAhaem-Petehaem, 1996) hlm.140.

20 Ibid.,hlm. 142.

21 Jan Remmelink, Op.cit., hlm.492. 
dihukum haruslah setara dengan perbuatanya atau dikenal dengan adagium klasik: perquod quis peccat, per huc punietur et idem. ${ }^{22}$ Sejak tahun 1886, di Belanda pandangan tersebut sudah berubah, dimana pencabutan hak yang semulanya tidak mengenal pembatasan kemudian dibatasi waktunya serta tidak dengan sendirinya berlaku bagi seseorang yang melakukan suatu kejahatan. Bila ingin diterapkan haruslah melalui putusan hakim. ${ }^{23}$ Hakim dalam menjatuhkan sanksi pencabutan hak melihat apa yang dianggapnya adil atau patut (rechtvaarding) serta berdayaguna (doelmatig). Namun, pencabutan hak tersebut tidak berlaku seumur hidup (restitutio in intergrum), kecuali pidana pokok yang dijatuhkan adalah seumur hidup. ${ }^{24}$ Pembuat undang-undang berkenaan dengan pencabutan hak tersebut kiranya memandang bahwasannya perampasan hak sebagai sanksi yang setimpal dan secara tegas merumuskan hak-hak apa saja yang dapat dikenakan perampasan.

Di Indonesia sendiri pencabutan hak diatur dalam undang-undang nomor 31 tahun 1999 tentang pemberantasan tindak korupsi, pada pasal 18 ayat (1). ${ }^{25}$ Numun, pidana tambahan dalam undang-undang pemberantasan tindak pidana tidak mengatur tentang pencabutan hak politik. Dalam undang-undang a quo hanya mengatur mengenai pidana tambahan perampasan barang maupun pemberian uang pengganti. Berbeda dalam undang-undang nomor 7 tahun 2017 tentang pemilihan umum. Di mana dalam pasal 240 ayat (1) huruf g menyebutkan bahwa "Bakal calon anggota DPR, DPRD provinsi, dan DPRD kabupaten/ kota adalah Warga Negara Indonesia dan harus memenuhi persyaratan" yaitu huruf $g$ "tidak pemah dipidana penjara berdasarkan utusan pengadilan yang telah memperoleh kekuatan hukum tetap karena melakukan tindak pidana yang diancam dengan pidana penjara 5 (lima) tahun atau lebih, kecuali secara terbuka dan jujur mengemukakan kepada publik bahwa yang bersangkutan mantan terpidana". Hal yang mengganjal adalah ketika terdapat pembatasan larangan bagi eks terpidana korupsi mencalonkan diri, tetapi diberikan pengecualian yang akhirnya mengijinkan menjadi calon legislatif ketika telah melakukan deklarasi bahwa sebelumnya yang bersangklutan sudah pernah dipidana. Terdapat peraturan yang memang membatasi hak politik yaitu Peraturan KPU No. 20 Tahun 2018 yang melarang eks terpidana korupsi untuk mencalonkan diri. Perturan a quo secara

22 Ibid.hlm.493.

23 Ibid.

24 Ibid.,hlm. 494.

25 Selain pidana tambahan sebagaimana dimaksud dalam Kitab Undang-undang Hukum Pidana, sebagai pidana tambahan adalah: a. perampasan barang bergerak yang berwujud atau yang tidak berwujud atau barang tidak bergerak yang digunakan untuk atau yang diperoleh dari tindak pidana korupsi, termasuk perusahaan milik terpidana di mana tindak pidana korupsi dilakukan, begitu pula dari barang yang mengantikan barang-barang tersebut; b. pembayaran uang pengganti yang jumlahnya sebanyak-banyaknya sama dengan harta benda yang diperoleh dari tindak pidana korupsi. c. Penutupan Seluruh atau sebagian perusahaan untuk waktu paling lama 1 (satu) tahun; d. Pencabutan Seluruh atau sebagian hak-hak tertentu atau penghapusan Seluruh atau sebagian keuntungan tertentu, yang telah atau dapat diberikan oleh Pemerintah kepada terpidana. 
filosofis memenuhi konsep ratio legis adanya pidana tambahan dengan konsep yang berlaku di Roma yaitu mengenai pienes "infamantes" di mana pencabutan hak politik diterapkan tanpa mnelalui putusan pengadilan, di mana secara otomatis karena yang bersangkutan melakukan tindak pidana korupsi sebagai extraordinary crime maka yang bersangkutan kehilangan hak politiknya. Namun, Peraturan KPU No. 20 Tahun 2018 yang mengatur pencabutan hak politik kemudian dibatalkan oleh Mahkamah agung lewat prosedur uji materil dalam putusan perkara nomor $46 \mathrm{P} /$ HUM/2018. Memang antara Peraturan KPU No. 20 Tahun 2018 dan undang-undang nomor 7 tahun 2017 tentang pemilihan umum pasal 240 ayat (1) huruf g telah terjadi konflik norma, sehingga untuk menyelesaikan konflik norma secara vertical diberlakukan asas preferensi hukum yakni lex superior derogat legi inferior UU pemililu yang secara hirarkis peraturan perundang-undangan memiliki kedudukan yang lebih tinggi sehingga peraturan KPU yang kedudukan lebih rendah dikesampingkan.

Pidana tambahan secara eksplisit diatur dalam Kitab Undang-Undang Hukum Pidana (selanjutnya disingkat KUHP) pada pasal 10 yaitu:26

1. Pencabutan hak hak tertentu.

2. Perampasan barang-barang tertentu

3. Pengumunan putusan hakim.

Mengenai pencabutan hak tersebut kemudian dijabarkan kembali dalam Pasal 35 ayat (1) KUHP yang didalamnya menyatakan bahwa, hak-hak terpidana yang dengan putusan hakim dapat dicabut yakni hak memegang jabatan pada umumnya atau hak memegang jabatan tertentu, hak memilih dan dipilih dalam pemilihan yang diadakan berdasarkan aturan-aturan umum. ${ }^{27}$ Pasal 35 KUHP secara gamblang menyatakan bahwa hakim dalam putusannya dapat menjatuhkan pidana tambahan yakni pencabutan hak-hak tertentu yang didalamnya mencakup hak memilih dan dipilih. Hal ini berarti bahwa hakim mempunyai kewenangan untuk mencabut hak memilih dan dipilih sebagai bagian dari hak politik warga Negara. Terpidana yang dihukum dalam pidana pokok dapat juga dikenakan pidana tambahan yakni hak politiknya dicabut sehingga yang bersangkutan tidak lagi memiliki hak untuk memilih dalam pemilihan umum bahkan hak untuk mencalonkan diri menjadi anggota legislatif dengan sendirinya akan hilang.

Hak politik terpidana dalam Pasal 35 KUHP memang dimungkinkan untuk dicabut lewat putusan hakim. Tetapi dalam Pasal 38 KUHP memberikan pembatasan dalam pencabutan hak terpidana, dimana dalam hal putusan hakim menghukum pidana mati atau seumur hidup, maka lamanya pencabutan hak adalah seumur hidup. Ketika hakim menjatuhkan hukuman pidana penjara dalam kurun waktu tertentu atau pidana kurungan, maka lamanya pencabutan hak adalah paling sedikit dua tahun dan paling banyak adalah 
lima tahun lebih lama daripada pidana pokok. ${ }^{28}$ Pasal 38 KUHP menunjukkan bahwasanya dalam penjatuhan pidana tambahan haruslah didahului dengan pidana pokok, karena batas waktu lamanya pidana tambahan pencabutan hak tersebut mengikuti pidana pokok. Bilamana pidana pokok adalah penjara dalam waktu tertentu maka pencabutan hak menggunakan ukuran minimum dan maksimum. Minimum adalah dua tahun dan maksimum adalah lima tahun lebih lama dari pidana pokok. Contoh, ketika terpidana diputus sembilan tahun penjara makan maksimum pidana tambahan pencabutan hak politik tidak boleh melebihi lima tahun, sehingga terpidana maksimum empat belas tahun tidak diperbolehkan untuk mengikuti pemilihan ataupun mencalonkan diri dalam pemilihan umum. Namun, pencabutan hak tersebut hanya bersifat temporer yang berarti ketika sudah melebihi empat belas tahun yang bersangkutan dikembalikan lagi hak politiknya untuk dipilih dan memilih.Bahkan seseorang yang haknya telah dicabut lewat putusan hakim dan ingin tetap menggunakan hak tersebut maka orang tersebut dapat dipidana sebagaimana yang diatur dalam Pasal 227 KUHP bahwa:"Barang siapa melaksanakan suatu hak, padahal ia mengetahui bahwa dengan putusan hakim hak tadi telah dicabut, diancam dengan pidana penjara paling lama sembilan bulan atau pidana denda paling banyak sembilan ratus rupiah". ${ }^{29}$

28 Pasal 38 Kitab Undang-Undang Hukum Pidana. 29 Pasal 227 Kitab Undang-Undang Hukum Pidana. 30 Jan Remmelink,Op.cit., hlm.496.
Dari isi Pasal 277 KUHP mempertegas bahwa pencabutan hak oleh hakim (hak untuk memilih dan dipilih) jika dilanggar, tentunya memiliki akibat hukum dapat dipidananya orang yang melanggar tersebut.Dengan demikian, pidana tambahan sebagaimana dalam Pasal 10 junto Pasal 35 junto Pasal 38 KUHP memiliki daya paksa untuk harus ditaati dengan ancaman pidana bagi yang melanggar sebagaimana yang telah diatur dalam Pasal 227 KUHP.

Konflik yang cenderung akan muncul ketika pencabutan hak tersebut yaitu mengenai jabatan yang wajib dilaksanakandan hakim melarang pemenuhannya. Oleh karena itu harus adanya pemecatan agar tidak ada konflik antara pencabutan hak yang di dalamnya terdapat kewajiban untuk melaksanakan tugas dan putusan hakim. Hal tersebut kemudian diterima oleh Hoge Raad pada 7 November 1910, W. 9086..$^{30}$ Dengan demikian, ketika ada pencabutan hak politik jika yang bersangkutan masih menjabat, maka haruslah diikuti dengan pemecatan. Perlu untuk diluruskan makna kata "pejabat", hal ini dikarenakan dalam KUHP tidak menjelaskan pengertian dari jabatan (ambt). Pasal 84 Straf Recht (KUHP Belanda) menyebutkan bahwa, ihwal dari pejabat dirumuskan sangat luas dimana didalamnya mencakup mereka yang dipilih dalam pemilihan umum sesuai dengan undang-undang dan kemudian menduduki jabatan tertentu dengan mereka 
yang menduduki jabatan sebagai anggota angkatan bersenjata. Hoge Raad (Mahkamah Agung Belanda) meluruskan kekeliruan tersebut dengan memberikan definisi bahwa mereka yang dipilih, ditunjuk atau diangkat oleh kekuasaan umum dalam hubungannya dengan pekerjaan publik yakni melaksanakan sebagian tugas-tugas Negara atau organorgannya (25 oktober 1915, NJ 1915, 1203, W 9861). ${ }^{31}$ Dari pengertian Hoge Raad dapat dilihat bahwa pencabutan hak politik terhadap pejabat dalam jabatannya (ambt) adalah jabatan yang diperoleh dari hasil pemilihan umum. Hal ini yang penulis maksud pencabutan hak politik dimana hak yang didapatkan dari proses pemilihan umum untuk menjadi pejabat kemudian dicabut, sehingga yang bersangkutan tidak dapat mencalonkan diri selama batas waktu yang ditentukan lewat putusan hakim.

Uraian diatas mendeskripsikan konsep dari pencabutan hak politik yang tidak lepas dari historis munculnya pidana tambahan di mana juga telah menjelaskan ratio legis munculnya pidana tambahan dalam KUHP yang merupakan produk peninggalan Belanda, yang secara historis diturunkan dari Roma ke Prancis kemudian Prancis ke Belanda dan akhirnya Belanda ke Indonesia. Secara konseptual, pidana tambahan merupakan perwujudan dari peines infarmantes, sebagaimana telah diatur dalam Code Penal yang berlaku sampai tahun 1886. Tindak pidana korupsi digolongkan sebagai extraordinary crime atau kejahatan luar biasa, sehingga prinsip peines infarmantes diberlakukan pada pejabat yang terbukti melakukan tindak pidana korupsi. Namun, kelemahan dari prinsip peines infarmantes yakni tidak adanya kekuatan hukum yang didalamnya mencakup kepastian hukum, di mana hak tersebut dicabut tanpa melalui prosedur putusan pengadilan. KUHP sendiri tidak membatasi pidana tambahan pencabutan hak tersebut sehingga ketika hakim menjatuhkan putusan, maka putusan tersebut tidak berlaku secara permanen. Dengan mengkaitkan antara tujuan pidana kontemporer dan tujuan sistem peradilan pidana sebagai langkah preverentif, serta mengingat tindak pidana korupsi sebagai extraordinary crime, maka konsep baru yang dihasilkan yaitu memberlakukan pidana tambahan pencabutan hak politik secara permanen terhadap terpidana korupsi sesuai dengan prinsip peines infarmantes namun dengan melalui proses litigasi atau lewat putusan pengadilan, agar dapat mempunyai kekuatan hukum yang mengandung kepastian hukum dimana putusan tersebut bersifat permanen atau berlaku seumur hidup (restitutio in intergrum). Hal ini sesuai dengan penilaian hakim dalam menjatuhkan sanksi pencabutan hak, yakni dengan melihat apa yang dianggapnya adil atau patut (rechtvaarding) serta berdayaguna (doelmatig). 
B. Pencabutan Hak Politik Bagi ada di dalam lautan di mana tidak ketahuan Terpidana Korupsi Dalam apakah mereka sedang minum ataukah Perspektif Teori Kontrak Sosial tidak. ${ }^{35}$ Ruslan mengutip pendapat Jeremy (Social Contract Theory).

Dewasa ini, di era globalisasi pada abad ke 21 kejahatan sudah berkembang dan menumbuhkan kejahatan baru yaitu tindak pidana transnasional yakni salah satunya adalah korupsi. ${ }^{32}$ Korupsi juga adalah kejahatan luar biasa (extraordinary crimes) yang semula berawal dari perbuatan suap. ${ }^{33}$ Secara etimologis, kata korupsi berasal dari bahasa latin corruption atau corroptus. Dalam bahasa latin, kata corruption juga berasal dari kata corrumpere. Dari bahasa latin itulah kemudian diturunkan dalam bahasa ni Negaranegara eropa seperti Inggris (corruption, corrupt), Prancis (corrupratio), dan Belanda (corruption yang dibaca korruptie) dari bahasa Belanda inilah kemudian turun kedalam bahasa Indonesia “korupsi”. ${ }^{34}$ Dahulu ada seorangfilsuf dari India yang bernama Kautilya. Suatu hari ada seseorang yang bertanya kepada filsuf tersebut tentang berapa banyak uang rakyat yang dijarah oleh pamong praja. Kautilya kemudian menjawab, mustahil bisa menghitungnya, mereka ibarat ikan yang Pope bahwa korupsi adalah menyalahgunakan kepercayaan untuk kepentingan pribadi. ${ }^{36}$

Bertolak dari pendapat Pope tersebut, bisa dilihat bahwa ada keterkaitan antara korupsi dengan teori kontrak sosial yang menyatakan bahwa hukum dianggap sebagai kehendak bersama dari sebuah konsensus (perjanjian) dengan seluruh anggota masyarakat. ${ }^{37}$ Konsensus tersebut ibarat sebuah kontrak yang pada umumnya didalam setiap kontrak, terdapat prinsip kebebasan berkontrak dan setiap kebebasan berkontrak mengandung prinsip konsesualisme serta kekuatan mengikat perjanjian. ${ }^{38}$ Prinsip kebebasan berkontrak didalamnya menyangkut integrity atau kebebasan, sehingga terdapat hak fundamental mengenai harkat dan martabat manusia dimana secara langsung berdampak terhadap kualitas hidup maupun kesejahteraan pribadi hingga kesejahteraan manusia dalam hidup bersama. ${ }^{39}$ Sebuah kontrak adalah wujud yang diimplementasikan dari hak hidup, kebebasan dan hak milik yang kemudian dimasukan dalam hukum dengan tujuan menghormati

32 Romli Atmasasmita, Hukum Kejahatan Bisnis di Era Globalisasi, (Jakarta: Prenada MediaGroup, 2014) hlm.1.

33 Ibid.,hlm.62.

34 Ruslan Renggong, Hukum Pidana Khusus Memahami Delik-Delik di Luar KUHP, (Jakarta: Kencana, 2016), hlm.60.

35 Ibid.,hlm.58.

36 Ibid.,hlm.61.

37 H. Lili Rasjidi \& Liza Sonia Rasjidi, Dasar-dasar Filsafat dan Teori Hukum, (Bandung: Citra $\quad$ Aditya Bakti, 2012), hlm.83.

38 Zulfirman, "Kontrak Sebagai Sarana Mewujudkan Kesejateraan Sosial", Rechtsvinding Vol.6, No.3,(Desember2017):407, diakses 11 Maret 2019, doi:https://rechtsvinding.bphn.go.id/artikel/

39 Ibid. : 418. 
dan memenuhi hak asasi manusia. ${ }^{40}$ Dari penjelasan pengertian kontrak umum di atas, dapat dimengerti bahwa suatu kontrak umum didalamnya mencakup kebebasan dan merupakan implementasi dari hak asasi manusia, apalagi kontrak sosial yang cakupan lebih luas dimana mencakup masyarakat dan Negara. Kontrak sosial yang dituangkan dalam konsensus dituangkan dalam pemilihan umum pada saat rakyat menyepakati untuk memberikan kebebasan mereka kepada Negara dan Negara mendapatkan kekuasaan yang bersumber dari kebebasan rakyat. Hal ini juga memperlihatkan bahwa rakyat dengan menyatakan kehendak bersama untuk menjadikan seseorang menjadi penguasa. Namun, ketika orang tersebut melakukan korupsi, maka hal tersebut menurut Pope sudah merusak kepercayaan rakyat untuk kepentingan pribadi.

Beranjak dari sini, sudah seyogianya seorang yang sudah melakukan tindak pidana korupsi sebagai kejahatan berat atau luar biasa (extraordinary crimes) tidak berhak mencalonkan dirinya kembali.Salah satu faktor yang membuat korupsi menjadi kejahatan luar biasa adalah karena tindak pidana korupsi berdampak pada turunnya kedisiplinan sosial yaitu pada saat uang suap diberikan maka akan berpengaruh terhadap prosedur administrasi, sehingga menjadi lambat dan dalam pelaksanaan rencanarencana pembangunan yang sudah diputuskan akhirnya dipersulit. ${ }^{41}$ Pencabutan hak politik oleh karena itu seyogianya diterapkan kepada pelaku yang melakukan tindak pidana korupsi, tetapi sangat disayangkan secara yuridis tidak mengatur pencabutan hak politik itu secara permanen. Atas dasar itu, penulis akan melihat dari sudut pandang atau perspektif teori kontrak sosial tentang pencabutan hak politik terpidana korupsi.

Di Cina, efek jera untuk koruptor diterapkan secara tegas oleh PM China Zhu Rongji atau yang dikenal dengan sebutan 'Mr.Clean. Beliau berangkat dari adagium cina kuno yaitu "bunuhlah seekor ayam untuk menakuti seribu ekor kera”. Paska diterapkannya aturan tersebut, RRC berhasil mengembalikan dana publik sebesar Rp. 440 milliar. $^{42}$ Jika adagium cina tersebut diterapkan terhadap tindak pidana korupsi dalam penjatuhan sanksi pidana tambahan berupa pencabutan hak politik, maka hal tersebut dimaksudnya untuk menakuti-nakuti agar pejabat yang lain merasa takut untuk melakukan tindakan korupsi.

Tindak pidana korupsi merupakan kejahatan berat kerena tidak hanya merugikan individu tapi juga rakyat, sehingga perlu untuk

40 Ibid.

41 Nia Putriyana dan Shintiya Dwi Puspita, “Tanggungjawabhukum Dalam Konteks Perbuatan Melawan Hukum Terhadap Tindak Pidana Korupsl”, Arena Hukum Vol. 7, No.3,(Desember2014):449,diakses12Maret2019,doi:https://arenahukum.ub.ac.id/index.php/arena/article/ view/173

42 Aulia Milono, "Formulasi Pedoman Penjatuhan Sanksi Pidana Terhadap Penyelenggara Negara Yang Melakukan Tindak Pidana Korupsi Di Indonesia", Arena Hukum Vol. 7, No.1,(April 2014):122,diakses12Maret2019,doi:https://arenahukum.ub.ac.id/index.php/arena/article/view/169 
memahami secara filosofis untuk menemukan dasar ontologis mengenai kedaulatan rakyat berdasarkan konstitusi sebagaimana dimuat dalam Undang-Undang Dasar Negara Republik Indonesia Tahun 1945 Pasal 1 ayat (2) bahwa, "kedaulatan berada di tangan rakyat dan dilaksanakan menurut UndangUndang Dasar”. Berikut penulis menguraikan secara filosofis kedaulatan rakyat dalam perspektif teori kontrak sosial dikemukakan oleh Thomas Hobbes, John Locke dan Jean Jacques Rousseau serta kaitannya dengan pencabutan hak politik secara permanen bagi terpidana tindak pidana korupsi sebagai kejahatan luar biasa (extraordinary crimes).

\section{Teori Kontrak Sosial Thomas Hobbes}

Thomas Hobbes dalam bukunya De Cive, 1642 (tentang warganegara) Leviatan or the matter, from and power of a commonwealth, ecclesiastical and civil, $1651^{43}$ mencari tentang sebab timbulnya Negara. Berbeda dengan Grotius yang menyatakan bahwa manusia cenderung hidup bersama dan itu merupakan bagian dalam diri manusia, tetapi Hobbes menyatakan sebaliknya bahwa manusia sejak zaman purbakala seluruhnya telah dikuasai oleh nafsu-nafsu alamiah untuk memperjuangkan kepentingannya sendiri. Hal tersebut dikarenakan, secara konkrit belum adanorma-norma yang mengatur tentang manusia untuk dapat hidup bersama, serta manusia primitif mempunyai hak atas segalanya. Konsekuensinya adalah terjadinya perang antara semua orang melawan semua orang atau dalam bahasa latin dikenal dengan bellum omnium contra omnes, yang tujuannya adalah untuk merebut apa yang dianggap haknya. Hal ini dikarenakan menurut Thomas Hobbes, pada dasarnya manusia sangat kompetitif, saling tidak mempercayai, dan mengutamakan kebebasan dirinya sendirihal itu membuat hubungan antar manusia seolah-olah semacam perang atau saling berhadapan satu sama lainnya. ${ }^{44}$ Pada saat itu dapat disimpulkan bahwasanya dalam hati manusia primitif, terdapat kecurigaan dan keangkuhan sehingga setiap individu saling menyerang yang akhirnya memunculkan ungkapan homo homini lupus artinya, manusia menjadi serigala bagi manusia lain. ${ }^{45}$ Agar terciptanya suasana yang damai, akhirnya mereka (pactum unios) mengusulkan perjanjian antara semua orang dengan seseorang tertentu (pactum subjectionis) dimana terjadi penyerahan kekuasaan yang diberikan kepada pemimpin dan bersifat mutlak serta absolute. ${ }^{46}$ Sebelum terjadi penyerahan kekuasaan tersebut, terdapat petunjuk-petunjuk yang harus dipenuhi yakni pertama, carilah damai. Kedua, serahkanlah hak aslimu. Ketiga berlakulah kepada orang lain seperti yang kamu ingin orang orang lain

43 Theo Huijbers, Filsafat Hukum Dalam Lintasan Sejarah, (Yogyakarta: Kanisius, 1982), hlm.63.

44 Ari Dwipayana, “Antara Leviathan dan Hukum Ikan”, Jurnal Ilmu Sosial dan Ilmu Politik, Volume 3 Nomoer 2, November 1999, Universitas Gadjah Mada, hlm. 194.

45 Ibid.,hlm. 65.

46 H. Lili Rasjidi \& Liza Sonia Rasjidi, Loc.cit.,hlm.83. 
perlakukan kepadamu, Keempat, tepatilah janji-janjimu. ${ }^{47}$

Petunjuk yang terakhir mengenai janjijanji yang harus ditepati memang sangat penting, hal tersebut dikarenakan pertunjuk ini menjadi persetujuan yang fundamental dari semua persetujuan atau contract social. Misalnya, kontrak antar individutidak ada artinyaapabila didalam kontrak tersebut tidak terdapat jaminan bahwa janji itu pastiakan ditepati. Hobbes juga memandang pentingnya prinsip ini, bahwa janji harus ditepati yang disebutnya sebagai kontral asli. Kontrak asli ialah persetujuan para individu-individu dalam suatu kelompok untuk membentuk hidup bersama secara teratur. Persetujuan sosial asli inilah yang kemudian menjadi asal terbentuknya Negara. Hobbes menyatakan bahwa terbentuknya suatu Negara bukanlah akibat dari kecenderungan manusia untuk bermasyarakat sebagaimana yang dikatakah oleh Grotius, melainkan pembentukan suatu Negara merupakan wujud kontrak sosial dengan tujuan mengamankan dirinya dari serangan orang lain. ${ }^{48}$

Pandangan Hobbes memiliki makna filosofis yang mendalam dimana awalnya manusia memiliki sikap alamiah atau sifat dasar untuk menjadi serigala bagi manusia lain. Dikatakan manusia primitif yang selalu mengutamakan kepentingan sendiri. Hal ini sangat mirip dengan karakteristik dari koruptor yang mengutamakan kepentingan pribadi dan mengesampingkan kepentingan rakyat yang adalah sekumpulan individuindividu dengan kesepakatan memberikan hak kebebasan mereka kepada pejabat publik untuk menjalankan pemerintahan. Sangat jelas pandangan Hobbes menyatakan bahwa untuk mendapatkan hak masyarakat terdapat petunjuk-petunjuk, dimana salah satu petunjuk yang sangat esensial adalah menepati janji-janji. Kontrak sosial asli yang digambarkan oleh Hobbes pada saat ini terlihat jelas pada saat rakyat memilih pemimpin dalam pemilihan umum. Mereka menandatangani kontrak kesepakatan dimana hak rakyat diberikan atas dasar kepercayaan akan memimpin dalam jangka waktu periode tertentu untuk menentukan arah Negara ini.

Implikasi filosofis dari perspektif kontrak sosial Hobbes dimana petunjuk menepati janjitersebut dipandang sebagai hal yang sangat esensial. Jika janji itu dilanggar dengan melakukan tindak pidana korupsi, maka yang bersangkutan seharusnya tidak diperkenankan untuk mendapatkan kepercayaan itu kembali, karena hak yang rakyat berikan merupakan suatu pemberian yang harus dijaga dengan segenap hati serta kepentingan rakyat harus yang utama dibandingkan dengan kepentingan pribadi. Bilamana terjadi tindak pidana korupsi otomatis, baik itu langsung atau tidak langsung akan berdampak terhadap kepentingan rakyat. 


\section{Teori Kontrak Sosial John Locke}

John Lock sama seperti Hobbes juga menerangkan tentang timbulnya Negara dan hukum dengan cara melukiskan keadaan manusia waktu hidup di zaman primitif. Pada zaman itu, setiap orang hidup menurut hukum alam. Hukum alam memiliki aspek yang luas dimana didalamnya mencakup berbagai bidang, mulai dari kesehatan, kebebasan, serta hak milik. Pelanggaran atas setiap hak dapat dihukum oleh tiap-tiap individu, sebab setiap individu mempunyai kekuasaan hukum alam yang bersifat eksekutif (the executive power of the law of nature). Suatu ketika, orangorang primitif mulai beralih dari keadaan aslinya kepada keadaan sipil. Peralihan ini penting karena, kadang orang-orang kurang memahami mengenai hak-hak alam serta bersikap tidak adil dalam menilai hak-hak itu. Kekurangan itu harus dilengkapi dengan membuat suatu aturan yang dapat berlaku bagi setiap orang, sekaligus membuat suatu pemerintah yang menjaga pelaksanaan aturan tersebut. $^{49}$

Tujuan Negara adalah untuk menjamin hak-hak warganegara, dimana Lock menggunakan sebuah adagium romawi salus populi superma lex esto yang berarti hukum yang tertinggi ialah keselamatan bangsa. Sehingga menurut Lock, sudah seyogiaya Negara harus menjaga serta melindungi hak-hak warga negara. ${ }^{50}$ Peralihan manusia menuju keadaan sipil tidak menghilangkan hukum alam primitif. Buktinya ialah bahwa semua kontrak tetap pada prinsip hukum alam yaitu janji harus ditepati (keepingfaith).Tetapi, agar Negara dapat menjalankan fungsinya sebagai pengawal hukum, orang-orang kemudian menyerahkan sebagian hak-hak primitif mereka kepada Negara, sehingga tidak lagi sama seperti hak-hak primitif dimana setiap orang mengawal hak mereka sendiri melainkan sekarang sudah tugas Negara untuk mengawal hak-hak mereka. ${ }^{51}$ Lock kemudian membagi sistem kekuasaan menjadi tiga yakni legislatif, eksekutif dam federatif. Kekuasaan yang tertinggi adalah legislatif yaitu kekuasaan untuk membuat undang-undang. Namun, kekuasaan legislatif kemudian dibatasi secara absolute oleh rakyat. Rakyat berhak untuk merebut kekuasaan asli, jikalau pemerintah menyalahgunakan kekuasaannya dengan bertindak melawan tujuan Negara yakni sebagai penjaga serta pengawal hak-hak rakyat dimana kekuasaan itu terikat pada hukum alam yang tetap ada pada rakyat. ${ }^{52}$ Kekuasaan eksekutif adalah kekuasaan untuk melaksanakan undang-undang demi kepentingan umum, yang didalamnya terdapat hak prerogative sebagai hak istimewa. Terakhir kekuasaan federatif yang berhubungan dengan hubungan internasional..$^{53}$ 
Dari uraian teori kontrak sosial Locke, dapat dimengerti bahwa tujuan Negara adalah untuk melindungi serta menjaga hak-hak alamiah warganegara, dimana Negara lewat hukum mengawal hak warganegara yang sebagian hak mereka telah diberikan kepada Negara.Namun, jika Negara menyalahgunakan kekuasaan tersebut, maka rakyat berhak merebut kekuasaan asli yang dibentuk lewat kontrak sosial. Merebut kekuasaan asli berarti mencabut hak oknum pemerintah yang menyalahgunakan kekuasaan tersebut, untuk dapat memperoleh kekuasaan itu kembali. Dari sudut pandang Lock secara tegas melarang jika pemerintah dalam hal ini melakukan tindakan yang merugikan hak rakyat. Tindak pidana korupsi secara langsung maupun tidak langsung pasti berdampak bagi warganegara, dimana uang yang seharusnya untuk kesejahteraan rakyat, dicuri untuk kepentingan pribadi atau kelompok tertentu sehingga Negara atau pemerintah yang seyogianya menjaga aturan yang didalamnya menjamin hak-hak rakyat untuk memperoleh kesejatraan sosial ekonomi kemudian melanggar aturan tersebut dengan cara melakukan tindak pidana korupsi.

\section{Teori Kontrak Sosial Jean Jacques Rousseau.}

Jean Jacques Rousseau mengemukakan bahwa, manusia pada dasarnya adalah makhluk yang bebas serta otonom, dan secara alamiah memiliki nilai moral didalam dirinya. Kebebasan yang bebas serta otonom tersebut kemudian dikotori oleh kebudayaan ilmu pengetahuan dan teknologi dimana nilai moral yang melekat dalam diri manusia juga ikut tercemar.Oleh sebab itu, manusia perlu untuk kembali kedalam situasikehidupannya yang asli. Menjadi pertanyaan, apakah manusia dapat meraih kebebasan asli kembali agar perasaan moral itu menjadi nyata hingga dapat mengembalikan kemelaratan banyak orang. Berangkat dari pertanyaan ini kemudian Rousseau menulis buku yang berjudul $d u$ contrat social ou principles du droit politique, $1762 .^{54}$

Rousseau menyatakan bahwa manusia yang memiliki kebebasan asli dan kemudian hidup bersama akhirnya membentuk kehidupan bersama dengan orang lain yang juga memiliki kebebasan itu. Hal ini dapat terjadi melalui sebuah kontrak yang disebut Rousseau sebagai contrat social. ${ }^{55}$ Rousseau menekankan pada istilah volonte generale atau kehendak umum. Kontrak sosial adalah kehendak umum, sehingga kedaulatan berada di tangan rakyat. Rousseau secara tegas menolak pernyataan Locke dan Montesquie. Menurut Rousseau, tidaklah tepat kekuasaan itu dibagi-bagi, karena kekuasaan hanya ada satu yaitu di tangan rakyat. Memang terdapat fungsi membuat undang-undang, memerintah, mengadili dan sebagainya, tapi semua fungsi tersebut merupakan amanasi atau pengaliran 
dari satu kekuasaan yang tak terbagi yakni kekuasaan rakyat. ${ }^{56}$

Penulis mengambil istilah volonte generale dari Rousseau bahwasanya kehendak umum yang diciptakan dari suatu kontrak sosial ini penting untuk dijaga. Kebebasan asli diberikan kepada pemerintah namun kedaulatan penuh berada di tangan rakyat.Inilah yang pada saat ini dikenal sebagai Negara demokratis. Dari presprektif kontrak sosial Rousseau dimana kekuasaan tunggal ada ditangan rakyat kemudian berimplikasi kepada hak rakyat haruslah diutamakan. Dalam perkara tindak pidana korupsi, jika melihat secara filosofis ketika pejabat melakukan korupsi otomatis berdampak pada rakyat sehingga bukan lagi volonte generale melainkan kehendak pribadi untuk memperkaya diri sendiri.

Permasalahan yang timbul ketika pidana pencabutan hak politik harus dilakukan secara permanen ialah, bahwa hal tersebut bertentangan dengan konsep hak asasi manusia dan bahkan lebih jauh tentang keadilan. Sebagaimana ditegaskan dalam Internasional Covenant on Civil and Political Rights (ICCPR), pencabutan hak politik tidak boleh secara permanen. Namun bertolak dari pandangan Rosseau tentang kontrak sosial, sesungguhnya ketika seluruh individu bersepakat dalam kontrak sosial, maka sejatinya kebebasan individu mereka telah hilang, dan digantikan oleh kehendak umum (volonte generale) yang diikuti oleh tujuan-tujuan umum. Franberg dalam bukunya From Rechtsstaat to Universal Law Statemengatakan bahwa, diskriminasi adalah komponen yang tidak bisa dibuang dalam hukum. Diskriminasi tersebut tidak sematamata dimaknai sebagai diskriminasi dalam arti literal, tetapi diskriminasi untuk mencapai tujuan sosial bersama. Lebih tegas, Franberg mengatakan bahwa "the very function of law is fulfilled through discriminating between human categories for social purpose". ${ }^{57}$ Tentu diskriminasi semacam ini tidak boleh dimaknai sebagai suatu ketidakadilan. Karenapun, berdasarkan teori kontrak sosial Rosseau, keadilan itu harus mengakomodasi seluruh kepentingan umum.

Pada dasarnya Rosseau tidak pernah merumuskan apa itu keadilan. Sebagaimana dijabarkan oleh Anthony D'Amato dalam bukunya Analytical Jurisprudence Anthology, kita tidak pernah diajarkan apa itu keadilan, bahkan di sekolah-sekolah hukum, kita tidak diajarkan apa itu keadilan. Kita hanya dapat menilai keadilan dari tindakan tidak adil itu sendiri. Selanjutnya dalam buku yang sama, H.L.A Hart menjelaskan bahwa sesungguhnya keadilan merupakan gagasan tradisional, yang tujuannya adalah untuk memelihara dan memulihkan segala sesuatu kedalam keadaan yang seimbang dan sesuai dengan porsinya. ${ }^{58}$ Karenanya menurut penulis, pencabutan hak

56 Ibid.,hlm.90.

57 Åke Frändberg, From Rechtsstaat to Universal Law-State: An Essay in Philosophical Jurisprudence, (New York: Springer, 2014), p. 100.

58 Anthony D’Amato, Analytical Jurisprudence Anthology, (Ohio: Anderson Publishing Co., 1996), p. 235. 
politik secara permanen bukanlah bentuk diskriminasi, lebih-lebih tindakan yang dapat mencederai nilai keadilan. Sejatinya,hal tersebut dilakukan untuk tujuan sosial bersama guna mengembalikan seluruhnya ke dalam keadaan yang seimbang (balance). Selain itu, perlu diingat bahwa hak politik bukanlah hak yang merupakan non-derogable, ${ }^{59}$ karenanya, pencabutan terhadap hak politik sendiri tidak dapat dipandang sebagai wujud pelanggaran terhadap hak asasi manusia, kecuali jika hak memilih dan dipilihnya juga dicabut, ${ }^{60}$ dengan kata lain, dalam hal ini pencabutan hak politik tersebut hanya sebatas dalam pencalonan diri dalam jabatan politik.

Kajian secara keseluruhan oleh penulis akan ditampilkan dalam bentuk skema, agar dapat dipahami secara jelas bagaimana konsep pidana tambahan berupa pencabutan hak-hak politik terhadap pejabat yang melakukan tindak pidana korupsi jika dilihat dari perspektif kontrak sosial (social contract), mengingat bahwa kedaulatan tertinggi sejatinya berada di tangan rakyat, walaupun kemudian diserahkan kepada para pejabat yang dipercaya dapat menjalankan kehendak umum (volonte generale) guna tujuan-tujuan umum (bersama).

Di Indonesia pencabutan hak politik dijatuhkan terhadap terpidana Luthfi Hasan Ishaaq lewat putusan nomor $1195 \mathrm{~K} / \mathrm{Pid}$. Sus/2014. Dalam perkara a quo putusan yang telah memperolah kekuatan hukum tetap (inkracht van gewijsde) terdakwa dihukum pidana tambahan yaitu pada angka 3 "menetapkan mencabut hak Terdakwa untuk dipilih dalam jabatan publik". Ratio decidendi dalam putusan hakim untuk hal yang memberatkan menyatakan sebagai berikut: ${ }^{61}$

1. Perbuatan pidana yang dilakukan Terdakwa selaku anggota DPR RI telah meruntuhkan kepercayaan masyarakat terhadap Lembaga Perwakilan Rakyat;

2. Perbuatan Terdakwa selaku Presiden Partai Keadilan Sejahtera (PKS) memberikan citra buruk terhadap pilar demokrasi melalui Lembaga Partai Politik;

3. Terdakwa sebagai Penyelenggara Negara dan Petinggi Partai Politik seharusnya menjadi teladan kepada masyarakat untuk berperilaku jujur.

Dengan melihat ratio decidendi putusan hakim yang memberatkan terdakwa hingga mendorong diterapkannya pidana tmabahan pencabutan hak politik adalah hakim melihat bahwa memang seorang pejabat publik yang memiliki jabatan yang tinggi misalnya DPR RI ketika melakukan korupsi akan menurunkan kepercayaan rakyat. Hal ini kemudian memunculkan rasa skeptis terhhadap masyarakat. Karenanya, pencabutan hak politik secara permanen melalui putusan pengadilan menjadi cara

59 Ajie Ramadhan, Rully Herdita Ramadhani, Mei Susanto, "Kebijakan Pidana Mati dalam RKUHP Ditinjau dari Aspek Politik Hukum dan Ham". Arena Hukum Volume 11, Nomor 3, Universitas Brawijaya, 2018 , hlm. 613.

60 Dina Fajar Indah, dkk, "Pencabutan Hak Politik Pelaku Tindak Pidana Korupsi dalam Perspektif Hak Asasi Manusia, Jurnal Risalah Hukum, Volume 16 Nomor 2, Desember 2020, hlm. 80. 


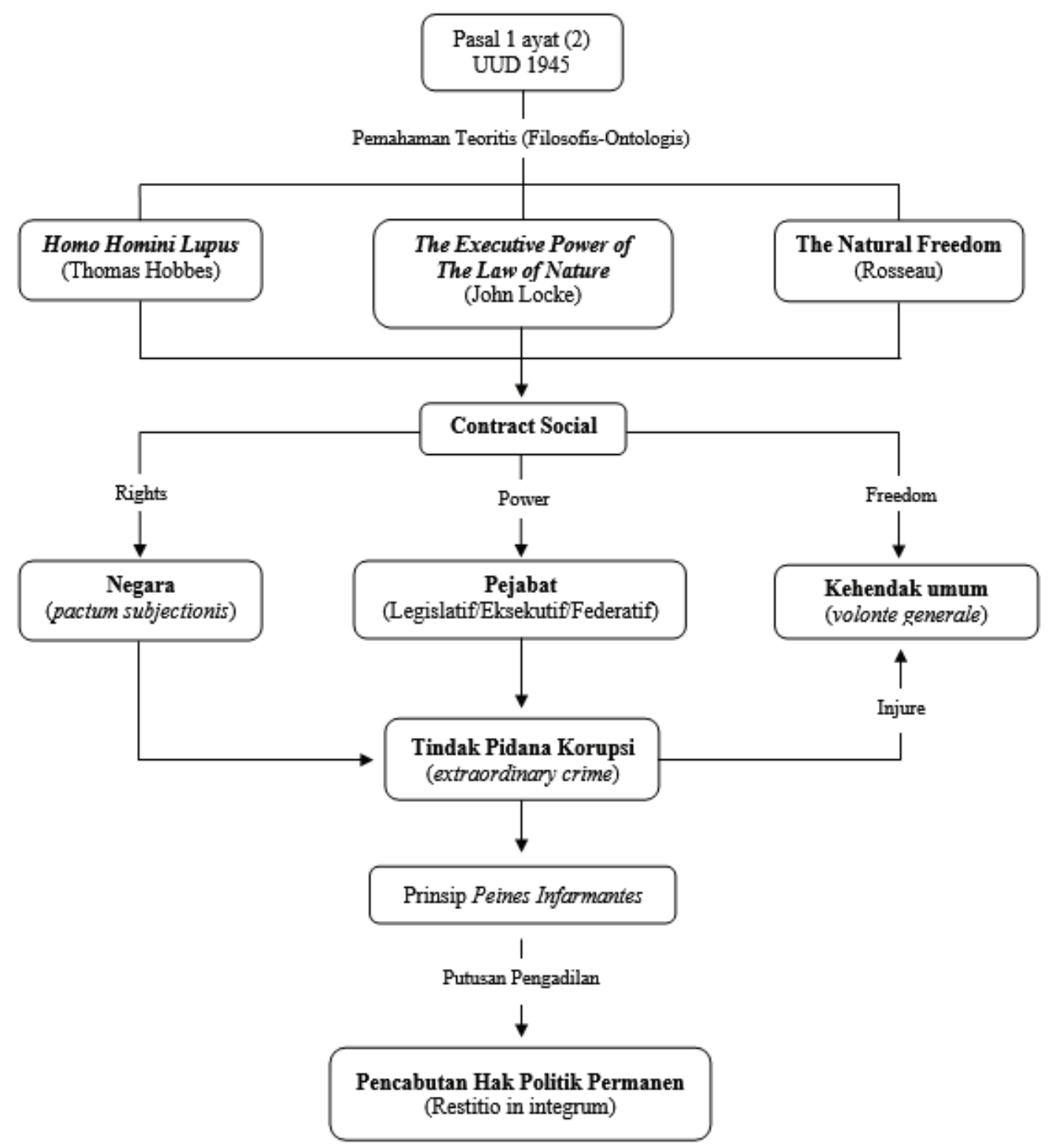

untuk mengembalikan rasa skeptic rakyat ke dalam keadaan semula atau seimbang dan memberikan kesempatan bagi wakil rakyat yang belum pernai menodai kepercayaan rakyat atau kehendak rakyat volonte generale seperti yang telah dikemukakan oleh H.L.A Hart bahwa sesungguhnya keadilan merupakan gagasan tradisional, yang tujuannya adalah untuk memelihara dan memulihkan segala sesuatu kedalam keadaan yang seimbang dan sesuai dengan porsinya. ${ }^{62}$

\section{Simpulan}

Berdasarkan pembahasan di atas, maka penulis menarik kesimpulan bahwa di Indonesia, pidana pokok dirasa belum bisa memenuhi tujuan hukum pidana kontemporer khususnya terhadap tindak pidana korupsi sebagai extraordinary crime. Karenanya perlu adanya pidana tambahan untuk membantu pidana pokok dalam memenuhi tujuan hukum pidana tersebut. Konsep pencabutan hak tersebut secara historis berawal dari hukum 
di Romawi yang disebut Infamia. Konsep tersebut kemudian dimasukan dalam Code Penal dengan nama Pienes Infamantes. Namun, kelemahan dari prinsip peines infarmantes ini yakni tidak adanya kekuatan hukum yang didalamnya mencakup kepastian hukum, di mana hak tersebut dicabut tanpa melalui prosedur putusan pengadilan. Jika melihat tindak pidana korupsi sebagai extraordinary crime, maka menjadi urgensi untuk menerapkan pencabutan hak politik bagi pelaku yang terbukti melakukan tindak pidana korupsi. Penulis kemudian menawarkan konsep baru yaitu pemberlakukan pidana tambahan pencabutan hak politik secara permanen (restitutio in intergrum) terhadap terpidana korupsi sebagai kejahatan berat (extraordinary crime) sesuai dengan prinsip peines infarmantes. Namun, dalam menerapkan hal tersebut harus melalui proses litigasi atau lewat putusan pengadilan agar dapat berkekuatan hukum serta di dalamnya mengandung kepastian hukum.

Perspektif teori kontrak sosial Hobbes, Lock, dan Resseau memberikan pemahaman filosofis secara ontologis mengenai konstititusi yang menyatakan kedaulatan tertinggi berada di tangan rakyat. Berdasarkan hal tersebut, menurut penulis, pencabutan hak politik secara permanen merupakan hal yang dikehendaki oleh rakyat sebagai langkah preventif sebagaimana yang menjadi tujuan sistem peradilan pidana. Hal tersebut dapat mengembalikan keadaan yang seimbang, agar tidak ada lagi rasa skeptis dari rakyat terhadap wakilnya.

\section{DAFTAR PUSTAKA}

\section{Buku}

Frändberg, Åke. From Rechtsstaat to Universal Law-State: An Essay in Philosophical Jurisprudence. New York: Springer, 2014.

D’Amato, Anthony.Analytical Jurisprudence Anthology. Ohio: Anderson Publishing Co., 1996.

Hiariej, Eddy O.S. Prinsip-Prinsip Hukum Pidana Edisi Revisi. Yogyakarta: Cahaya Atma Pustaka, 2016.

Rasjidi,H. Lili dan Liza Sonia Rasjidi, Dasardasar Filsafat dan Teori Hukum, Bandung: Citra Aditya Bakti, 2012.
Remmelink, Jan.Hukum Pidana Komentar Atas Pasal-pasal Terpenting Dari Kitab Undang-Undang Hukum Pidana Belanda dan Padanannya Dalam Kitab Undang-Undang Hukum Pidana Indonesia. Jakarta: Gramedia Pustaka Utama, 2003.

Atmasasmita ,Romli.Sistem Peradilan Pidana Kontemporer. Jakarta: Kencana, 2010. Atmasasmita, Romli.Hukum Kejahatan Bisnis di Era Globalisasi. Jakarta: Prenadamedia Group, 2014.

Renggong, Ruslan.Hukum Pidana Khusus Memahami Delik-Delik di Luar KUHP. Jakarta: Kencana, 2016. 
Bakhri,Syaiful.Sistem Peradilan Pidana

di Indonesia Dalam Perspektif

Pembaruan, Teori, dan Praktik

Peradilan. Yogyakarta: Pustaka Pelajar, 2016.

Sianturi,S.R. dan Mompang L. Panggabean.

Hukum Penitensia di Indonesia.Jakarta:

Alumni Ahaem-Petehaem, 1996.

Huijbers, Theo. Filsafat Hukum Dalam

Lintasan Sejarah. Yogyakarta: Kanisius, 1982.

\section{Jurnal}

Zulfirman. "Kontrak Sebagai Sarana

Mewujudkan Kesejateraan Sosial”.

Rechtsvinding Vol. 6, No.3,(Desember 2017): 407.

Putriyana, Nia dan Shintiya Dwi Puspita.

"Tanggungjawabhukum Dalam

Konteks Perbuatan Melawan Hukum

Terhadap Tindak Pidana Korupsi”.

Arena Hukum Vol. 7, No.3, (Desember 2014): 449.

Milono, Aulia. "Formulasi Pedoman

Penjatuhan Sanksi Pidana Terhadap

Penyelenggara Negara Yang Melakukan

Tindak Pidana Korupsi Di Indonesia”.

Arena Hukum Vol. 7, No.1,(April 2014):

122.

Ajie Ramadhan, Rully Herdita Ramadhani,

Mei Susanto, “Kebijakan Pidana Mati

dalam RKUHP Ditinjau dari Aspek

Politik Hukum dan Ham". Arena

Hukum Volume 11 Nomor 3, (2018):

613.
Ari Dwipayana, "Antara Leviathan dan Hukum Ikan", Jurnal Ilmu Sosial dan Ilmu Politik, Volume 3 Nomor 2, (November 1999):194.

Sabungan Sibarani, "Analisis Hukum Mengenai Pencabutan Hak Politik Bagi Koruptor Berdasarkan Sudut Pandang Hak Asasi Manusia, Prosiding Seminar Nasional Pakar ke-2 Sosial dan Humaniora, 2019: 4.

Deny Ardiansyah, "Pencabutan Hak Untuk Memilih dan Dipilih Bagi Terpidana Tindak Pidana Korupsi”, Jurnal Cakrawala Hukum, Volume 8 No 2, (Desember 2017): 139-148.

Warih Anjari, "Pencabutan Hak Politik Terpidana Korupsi dalam Perspektif Hak Asasi Manusia, Jurnal Yudisial, Volume 8 Nomor 1, (April 2015): 24.

Mardenis, "Kontemplasi dan Analisis Terhadap Klasifikasi dan Politik Hukum Penegak HAM di Indonesia", Jurnal Rechtvinding, Volume 2 Nomor 3, (2013): 437-451.

Dina Fajar Indah, dkk, "Pencabutan Hak Politik Pelaku Tindak Pidana Korupsi dalam Perspektif Hak Asasi Manusia, Jurnal Risalah Hukum, Volume 16 Nomor 2, (Desember 2020): 80.

\section{Peraturan Perundang-Undangan}

Undang-Undang Dasar Negara Republik Indonesia Tahun 1945

Kitab Undang-Undang Hukum Pidana

Undang-Undang Nomor 7 Tahun 2017 tentang Pemilihan Umum. 
Undang-Undang Nomor 20 Tahun 2001 tentang Perubahan Atas UndangUndang Nomor 31 Tahun 1999 tentang Pemberantasan Tindak Pidana Korupsi. Peraturan Komisi Pemilihan Umum Nomor 20 Tahun 2018 tentang Pencalonan Anggota DPR, DPRD Provinsi, dan DPRD Kabupaten/Kota

\section{Putusan Pengadilan}

Putusan Mahkamah Agung Republik Indonesia Nomor 1195 K/Pid.Sus/2014. Putusan MahkamahAgung Republik Indonesia Nomor 28/Pid.Sus-TPK/2018/PT.DKI.

Putusan MahkamahAgung Republik Indonesia Perkara Nomor 46 P/HUM/2018.

\section{Website}

Moh. Dani Pratama Huzaini,“Update KPU, Jumlah Caleg Mantan Napi Koruptor,Bertambah,32Orang”https:// www.hukumonline.com/berita/baca/ 15 c6ca 7 a $634887 /$ iupdate-i-kpujumlah-caleg-mantan-napi-koruptor bertambah-32-orang.

Julian,. "Bupati.Ini.Ternyata.Residivis. Kasus.Korupsi”http://poskotanews. com/2018/01/06/bupati-ini-ternyataresidivis-kasus-korupsi/, diakses 20 mei 2019.

Dylan Aprialdo Rachman, "KPK: Hak Politik 26 Koruptor Dicabut Sepanjang2013-2017”, https://nasional.kompas.com/ $\mathrm{read} / 2018 / 09 / 18 / 13252541 / \mathrm{kpk}$-hakpolitik-26-koruptor-dicabutsepanjang-2013-2017 